\title{
IMPLEMENTASI TEKNOLOGI RFID PADA SISTEM ANTRIAN REKAM MEDIS PASIEN DI RUMAH SAKIT
}

\author{
Musfirah Putri Lukman ${ }^{1}$, Husni Angriani ${ }^{2}$ \\ 1musfirah@kharisma.ac.id, ${ }^{2}$ husniangriani@kharisma.ac.id \\ ${ }^{12}$ STMIK Kharisma Makassar
}

\begin{abstract}
Abstrak
Penelitian ini bertujuan untuk mengurangi waktu antri pasien ketika memproses rekam medis pada pendaftaran rawat jalan di rumah sakit. Untuk tujuan tersebut, maka diusulkan pemanfaatan Radio Frequency Identification (RFID) dimana RFID ini berguna sebagai kode unik pasien. Kode unik tersebut akan menampilkan data pasien secara otomatis sehingga tidak memerlukan waktu pencarian berkas pasien yang dapat menambah waktu antrian pasien. Teknik perancangan sistem pada penelitian ini menggunakan metode prototyping sedangkan teknik pengujian analisis data menggunakan metode analisis uji-T. Pengujian perangkat lunak menggunakan teknik pengujian black box. Hasil penelitian yang diperoleh adalah sistem mampu mempercepat proses antrian rekam medis pasien pada rumah sakit dengan waktu rata - rata sebesar 3.6 menit dengan selisih waktu 9.4 menit dari waktu rata - rata antrian untuk sistem konvensional sebesar 12.6 menit. Secara keseluruhan dapat disimpulkan bahwa rata-rata waktu antri sistem RFID lebih singkat daripada waktu antri sistem konvensional sehingga sistem RFID mampu mempersingkat waktu antri pasien untuk proses rekam medis.
\end{abstract}

Kata kunci: Radio Frequency Identification (RFID), Antrian, Rekam Medis, Rumah Sakit

\section{Pendahuluan}

Pencatatan data riwayat kesehatan pasien adalah hal yang penting dalam dunia medis dan dikenal dengan istilah data rekam medis. Selama pasien melakukan pemeriksaan atau menjalani perawatan medis oleh dokter atau suatu instansi medis, maka status kesehatan pasien akan dicatat sebagai data rekam medis pasien. Data rekam medis pasien tersebut dapat digunakan sebagai acuan untuk pemeriksaan kesehatan pasien selanjutnya, sekaligus sebagai bukti tercatat mengenai diagnosis penyakit pasien dan pelayanan medis yang diperoleh pasien. Kebanyakan rumah sakit di Indonesia masih menggunakan sistem konvensional dalam pencatatan arsip rekam medis pasien. Sistem konvensional dalam pencatatan dan pengarsipan rekam medis memiliki kekurangan, yaitu arsip yang bisa saja hilang ataupun rusak, membutuhkan waktu yang lama untuk mencari rekam medis seorang pasien dikarenakan penyimpanan arsip yang tidak tersusun secara teratur, waktu tunggu yang sangat lama bagi pasien yang memerlukan respon cepat untuk segera berobat.

Berdasarkan permasalahan yang telah dipaparkan di atas, penulis ingin mencoba membuat sistem antrian tunggu berbasis teknologi RFID sebagai kode unik dari pasien. Kode unik ini merupakan identitas pasien untuk memanggil secara otomatis database dari pasien. Dengan sistem ini diharapkan sistem antrian untuk proses rekam medis pasien dapat dilakukan secepat mungkin. Mekanisme sistem ini secara ringkas adalah tiap pasien memiliki satu kartu yang berfungsi sebagai tag RFID yang berisi kode unik tiap pasien, dimana jika diletakkan dekat dengan RFID reader maka sistem akan langsung memunculkan data pribadi beserta catatan rekam medis pasien. Dari latar belakang masalah yang telah dipaparkan di atas maka dapat diperoleh sebuah rumusan masalah. Rumusan masalah dalam penelitian ini adalah bagaimana mengimplementasikan teknologi RFID dalam sistem pengantrian pengambilan berkas rekam medis pasien di rumah sakit. Dari rumusan masalah yang telah disebutkan sebelumnya maka tujuan dari penelitian ini adalah untuk menerapkan konsep antrian otomatis dengan mengimplementasikan teknologi RFID dalam sistem antrian pengambilan berkas rekam medis pasien di rumah sakit.

\section{Metode}

Metode yang digunakan dalam sistem terbagi menjadi dua bagian yaitu metode perancangan dan metode pengujian sistem. Metode perancangan yang digunakan untuk merancang sistem adalah metode prototyping sedangkan metode pengujian sistem terdiri dari dua metode yaitu metode pengujian black box untuk menguji perangkat lunak sistem dan metode pengujian analisis uji T untuk menguji hasil pengambilan data dari perangkat keras (Arduino Uno). Adapun tahapan - tahapan penelitian yang akan ditempuh dengan metode prototyping dalam penelitian ini adalah[1]:

1. Rekayasa dan Pemodelan Sistem diawali dengan mencari kebutuhan dari keseluruhan sistem yang akan diaplikasikan ke dalam bentuk hardware dan software. 


\section{ILKOM Jurnal Ilmiah Volume 10 Nomor 1 April 2018}

2. Analisa Kebutuhan Perangkat Lunak dan Perangkat Keras bertujuan Untuk mengetahui sifat dari program dan hardware yang akan dibuat[9]. Dari sistem yang dikembangkan oleh penulis, terdapat beberapa fitur - fitur yang akan ada di dalam aplikasi untuk kebutuhan fungsional, yaitu:

- Sistem mampu mendata pasien yang terdaftar,

- Sistem mampu mendata dokter, pegawai, dan poli yang ada pada rumah sakit,

- Sistem mampu mendata pendaftaran rawat jalan pasien,

- Sistem mampu mendata rekam medis pasien,

- Sistem mampu menghitung pembayaran yang harus dibayar pasien.

Adapun kebutuhan non-fungsional dalam sistem yang dibuat penulis, antara lain:

- Laptop / Komputer untuk menjalankan aplikasi, dan Printer untuk mencetak bukti pembayaran dan rekam medis pasien,

- Sistem mampu memberikan respon cepat dalam membantu pasien melakukan proses perawatan di rumah sakit,

- Sistem mampu memberikan kemudahan dalam penggunaan dan fleksibel sehingga dapat sesuai dengan kebutuhan.[3]

3. Desain harus dapat mengimplementasikan kebutuhan yang telah disebutkan pada tahap sebelumnya baik hardware maupun software. Desain rancangan sistem dalam bentuk data flow diagram (DFD) dapat dilihat pada gambar 1 dan 2. Data flow diagram adalah representasi dari sebuah sistem secara grafis yang digambarkan dengan sejumlah simbol tertentu untuk menunjukkan perpindahan data dalam proses-proses suatu sistem. [2] Dari skema data flow diagram sistem maka dapat dilihat alur perpindahan data untuk sistem yang dibuat.

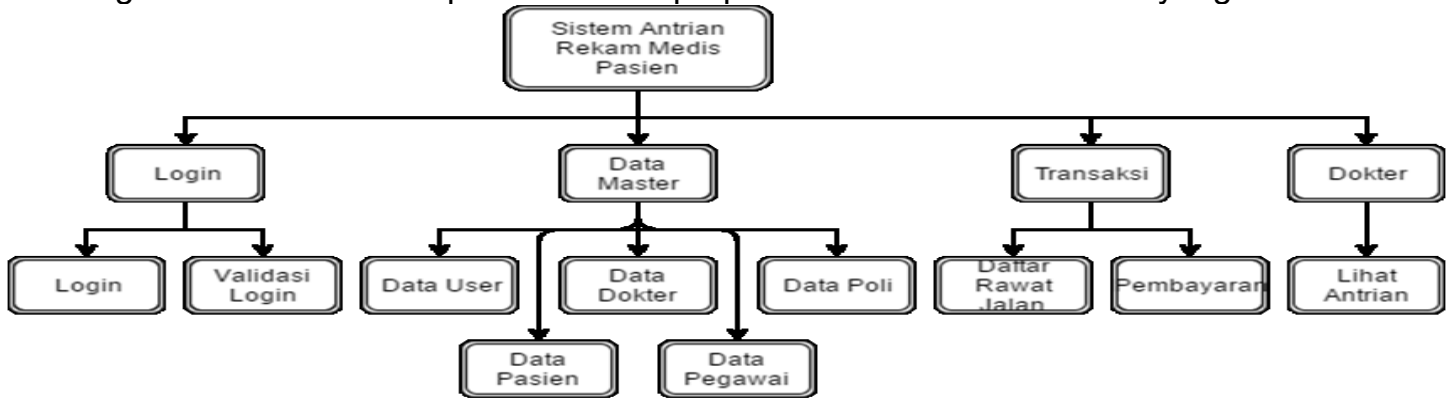

Gambar 1. Diagram Hirarki

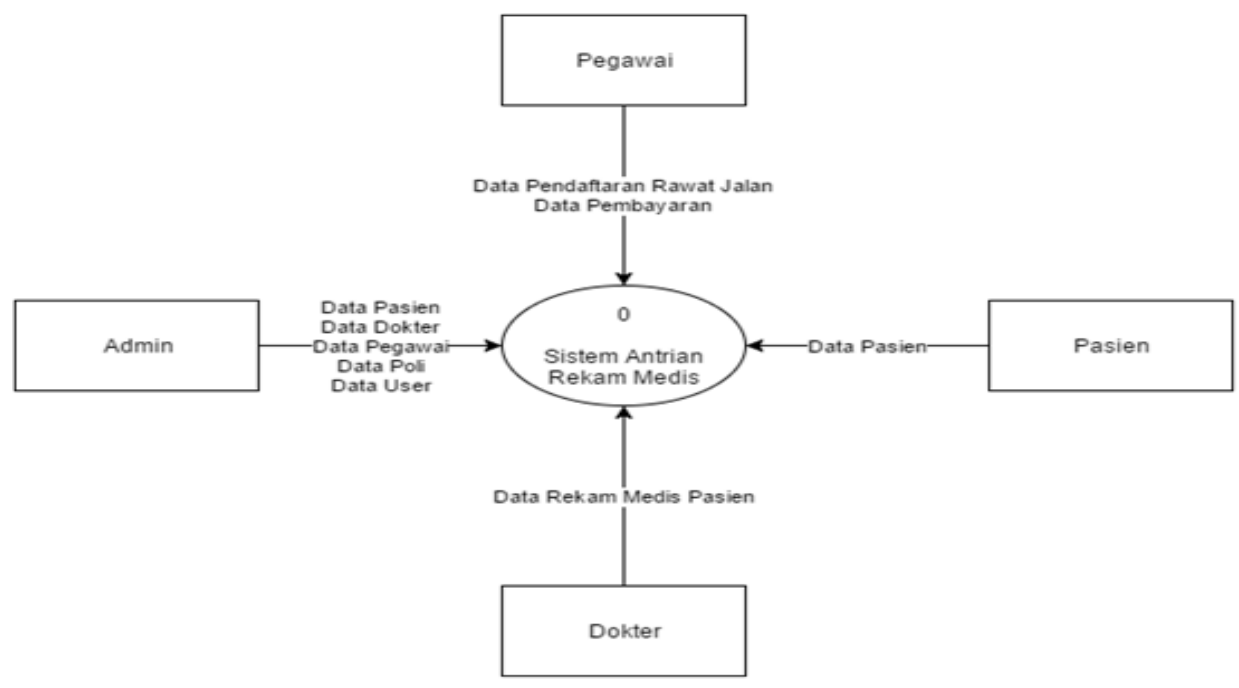

Gambar 2. Diagram Konteks

4. Coding merupakan tahap ini merupakan implementasi dari tahap design yang secara teknis nantinya dikerjakan oleh programmer.

5. Pengujian merupakan proses uji coba semua fungsi-fungsi software dan hardware agar software dan hardware bebas dari error, dan hasilnya harus benar-benar sesuai dengan kebutuhan yang telah didefinisikan sebelumnya. Pengujian black-box berfokus pada persyaratan fungsional perangkat lunak. Dengan demikian, pengujian black-box memungkinkan perekayasa perangkat 


\section{ILKOM Jurnal Ilmiah Volume 10 Nomor 1 April 2018}

lunak mendapatkan serangkaian kondisi input yang sepenuhnya menggunakan semua persyaratan fungsional untuk suatu program. Pengujian black-box berusaha menemukan kesalahan dalam kategori seperti fungsi - fungsi yang tidak benar atau hilang, kesalahan interface, kesalahan dalam struktur data atau akses eksterna, kesalahan kinerja, dan inisialisasi dan kesalahan terminasi. Teknik analisis data pada penelitian ini dilakukan untuk mengolah data penelitian. Dalam penelitian ini dilakukan uji beda atau uji t. Uji t adalah jenis pengujian statistika untuk mengetahui apakah ada perbedaan dari nilai yang diperkirakan dengan nilai hasil perhitungan statistika. Dalam penelitian ini dilakukan pengambilan sampel sebanyak 50 sampel pada setiap instrumen ukur. Perbedaan efektifitas dari masing-masing pengukuran dicari dengan rumus:

$$
D=Y_{1}-Y_{2}
$$

Dari hasil yang didapat dari perhitungan perbedaan efektifitas alat ukur, kemudian dicari mean difference dari pengukuran yaitu dengan rumus:

$$
M D=\frac{\sum D}{N}
$$

Dari hasil perhitungan Mean Different dilakukan pengujian hipotesis dengan menggunakan uji t, yang dirumuskan dengan rumus sebagai berikut:

$$
S_{D}^{2}=\left[\Sigma D^{2}-\left(\left(\frac{\Sigma D^{2}}{N}\right)\right) /(N-1)\right], \quad S=\sqrt{S_{D}^{2} / N}, \quad \mathrm{th}_{\text {hit }}=\left(\bar{Y}_{1}-\bar{Y}_{2) / \mathrm{S}}\right.
$$

Keterangan:

$Y_{1}=$ Waktu antrian Sistem Konvensional

$M D=$ mean difference

$Y_{2}=$ Waktu antrian Sistem RFID

$\sum D=$ jumlah perbedaan

$\sum D^{2}=$ jumlah deviasi perbedaan dikuadratkan

$\bar{Y}_{1}=$ jumlah rata-rata waktu antrian

$\mathrm{N}=$ jumlah sampel

$\bar{Y}_{2}=$ jumlah rata-rata waktu antrian sistem RFID konvensional

Pengujian pada penelitian ini menggunakan 3 studi kasus selama 3 pekan pada salah satu Rumah Sakit di Makassar. Studi kasus pertama mengambil 25 pasien dari total populasi 50 pasien yang diambil pada tanggal 28/11/2016 mulai dari pukul $08.00-11.00$. Studi kasus kedua mengambil sample sebanyak 30 pasien dari total 50 populasi yang diambil pada tanggal 1/12/2016 pukul 08.0011.00. Studi kasus ketiga mengambil sampel sebanyak 40 pasien dari total 50 populasi yang diambil pada tanggal 6/12/2016 pukul 08.00-11.00. Waktu minimum dari antrian untuk mengambil rekam medis pada rumah sakit adalah 10 menit, sedangkan waktu maksimum untuk mengambil rekam medis adalah 15 menit. Sedangkan waktu antrian untuk mengambil rekam medis dengan menggunakan sistem adalah 1 menit untuk waktu minimum dan 5 menit untuk waktu maksimumnya. Analisis data dan bukti antrian untuk pengambilan rekam medis akan dibahas lebih lanjut dalam studi kasus mendetail dengan hipotesis studi kasus berikut : $\mathrm{H}_{0}: \bar{Y}_{1}=\bar{Y}_{2}$ atau $\mathrm{H}_{\mathrm{A}}: \bar{Y}_{1} \neq \bar{Y}_{2}$ dengan keterangan $\bar{Y}_{1}$ adalah waktu antrian rata-rata sistem konvensional dan $\bar{Y}_{2}$ adalah waktu rata-rata antrian sistem berbasis RFID. Kriteria pengambilan keputusan adalah terima $\mathrm{H}_{0}: \mathrm{thit}_{2}<\mathrm{t}_{\text {tabel }}$ atau terima $\mathrm{H}_{\mathrm{A}}$ : $\mathrm{thit}_{\mathrm{it}}>\mathrm{t}_{\text {tabel. }}$ Data tabel analisis untuk studi kasus pertama, kedua, dan ketiga perlihatkan pada tabel 2. Data mentah untuk untuk waktu antrian dapat dilihat pada tabel 1.

Tabel 1. Tabel Data Waktu Antrian Secara Acak Pengujian untuk rumah sakit (Biru) dan sistem RFID (merah muda).

\begin{tabular}{|c|c|c|c|c|c|c|c|c|c|}
\hline No. & Menit & No. & Menit & No. & Menit & No. & Menit & No. & Menit \\
\hline $\mathbf{1}$ & 14 & 11 & 12 & 21 & 12 & 31 & 11 & 41 & 13 \\
\hline $\mathbf{2}$ & 10 & 12 & 13 & 22 & 15 & 32 & 11 & 42 & 11 \\
\hline $\mathbf{3}$ & 14 & 13 & 12 & 23 & 15 & 33 & 14 & 43 & 13 \\
\hline $\mathbf{4}$ & 12 & 14 & 13 & 24 & 12 & 34 & 12 & 44 & 13 \\
\hline $\mathbf{5}$ & 10 & 15 & 10 & 25 & 10 & 35 & 13 & 45 & 14 \\
\hline $\mathbf{6}$ & 15 & 16 & 12 & 26 & 14 & 36 & 10 & 46 & 15 \\
\hline $\mathbf{7}$ & 14 & 17 & 13 & 27 & 11 & 37 & 13 & 47 & 10 \\
\hline $\mathbf{8}$ & 15 & 18 & 15 & 28 & 13 & 38 & 12 & 48 & 11 \\
\hline $\mathbf{9}$ & 12 & 19 & 12 & 29 & 12 & 39 & 11 & 49 & 12 \\
\hline $\mathbf{1 0}$ & 14 & 20 & 14 & 30 & 11 & 40 & 10 & 50 & 12 \\
\hline
\end{tabular}

\begin{tabular}{|c|c|c|c|c|c|c|c|c|c|}
\hline No. & Menit & No. & Menit & No. & Menit & No. & Menit & No. & Menit \\
\hline 1 & 4 & 11 & 3 & 21 & 2 & 31 & 1 & 41 & 2 \\
\hline 2 & 5 & 12 & 5 & 22 & 5 & 32 & 5 & 42 & 2 \\
\hline 3 & 1 & 13 & 1 & 23 & 5 & 33 & 5 & 43 & 2 \\
\hline 4 & 4 & 14 & 1 & 24 & 2 & 34 & 3 & 44 & 3 \\
\hline 5 & 1 & 15 & 3 & 25 & 3 & 35 & 5 & 45 & 5 \\
\hline 6 & 2 & 16 & 2 & 26 & 1 & 36 & 3 & 46 & 1 \\
\hline 7 & 3 & 17 & 3 & 27 & 2 & 37 & 5 & 47 & 5 \\
\hline 8 & 3 & 18 & 1 & 28 & 3 & 38 & 4 & 48 & 1 \\
\hline 9 & 2 & 19 & 1 & 29 & 1 & 39 & 4 & 49 & 4 \\
\hline 10 & 3 & 20 & 4 & 30 & 5 & 40 & 5 & 50 & 5 \\
\hline
\end{tabular}




\subsection{Radio Frequency Identification (RFID)}

Identifikasi dengan frekuensi radio adalah teknologi untuk mengidentifikasi seseorang atau objek benda menggunakan transmisi frekuensi radio, khususnya $125 \mathrm{kHz}, 13.65 \mathrm{Mhz}$ atau 800 900MHz.[6] RFID menggunakan komunikasi gelombang radio untuk secara unik mengidentifikasi objek atau seseorang. [12] Identifikasi RFID bukan sekedar kode identifikasi, sebagai pembawa data, dapat ditulis dan diperbaharui data didalamnya dalam keadaan bergerak.[10] Terdapat beberapa pengertian RFID yaitu: RFID (Radio Frequency Identification) adalah sebuah metode identifikasi dengan menggunakan sarana yang disebut label RFID atau transponder (tag) untuk menyimpan dan mengambil data jarak jauh.[10] Dalam penelitian [13] mengatakan bahwa RFID tidak hanya sekedar pengganti barcode.

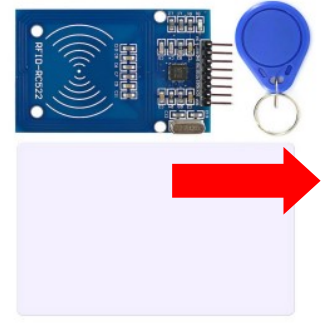

\subsection{Sistem Antrian}

Sistem antrian adalah kedatangan pelanggan untuk mendapatkan pelayanan, menunggu untuk dilayani jika fasilitas pelayanan (server) masih sibuk, mendapatkan pelayanan dan kemudian meninggalkan sistem setelah dilayani.[9] Dalam sistem antrian terdapat beberapa komponen dasar proses antrian antara lain adalah: Pertama, setiap masalah antrian melibatkan kedatangan, misalnya orang, mobil, panggilan telepon untuk dilayani, dan lain-lain. Proses input meliputi sumber kedatangan atau biasa dinamakan calling population, dan cara terjadinya kedatangan yang umumnya merupakan variabel acak. Kedua, pelayanan atau mekanisme pelayanan dapat terdiri dari satu atau lebih pelayan, atau satu atau lebih fasilitas pelayanan. Dalam mekanisme pelayanan ini ada 3 aspek yang harus diperhatikan yaitu:

1. Tersedianya pelayanan untuk loket pendaftaran pasien.

2. Kapasitas pelayanan yaitu jumlah pelanggan yang tidak dapat dilayani secara bersama-sama.

3. Lama pelayanan yaitu waktu yang dibutuhkan untuk melayani seseorang langganan atau satu satuan.

Pada umumnya dan untuk keperluan analisis, waktu pelayanan dianggap sebagai variabel acak yang dihasilkan secara acak dan bebas serta tidak tergantung pada waktu tiba. Ketiga, Antrian terutama tergantung dari sifat kedatangan dan proses pelayanan. Jika tak ada antrian berarti terdapat pelayan yang menganggur atau kelebihan fasilitas pelayanan.

\subsection{Rekam Medis}

Bentuk rekam medis manual yaitu rekam medis tertulis lengkap dan jelas sesuai ketentuan. Rekam medis terdiri dari catatan-catatan data pasien yang dilakukan dalam pelayanan kesehatan.[7] Dalam penjelasan Pasal 46 ayat (1) UU Praktik Kedokteran, yang dimaksud dengan rekam medis adalah berkas yang berisi catatan dan dokumen tentang identitas pasien, pemeriksaan, pengobatan, tindakan dan pelayanan lain yang telah diberikan kepada pasien. Dalam Peraturan Menteri Kesehatan Nomor 749a/Menkes/Per/XII/1989 tentang Rekam Medis dijelaskan bahwa rekam medis adalah berkas yang berisikan catatan dan dokumen tentang identitas pasien, pemeriksaan, pengobatan, tindakan dan pelayanan lain kepada pasien pada sarana pelayanan kesehatan. Kedua pengertian rekam medis di atas menunjukan pengaturan rekam medis pada UU Praktik Kedokteran lebih luas, berlaku baik untuk sarana kesehatan maupun di luar sarana kesehatan. Isi Rekam Medis:

a) Catatan, merupakan uraian tentang identitas pasien, pemeriksaan pasien, diagnosis, pengobatan, tindakan dan pelayanan lain baik dilakukan oleh dokter dan dokter gigi maupun tenaga kesehatan lainnya sesuai dengan kompetensinya.

b) Dokumen, merupakan kelengkapan dari catatan tersebut, antara lain foto rontgen, hasil laboratorium dan keterangan lain sesuai dengan kompetensi keilmuannya.

\section{Hasil dan Pembahasan}

Hasil dari penelitian ini adalah implementasi sistem dalam bentuk perangkat keras dengan menghitung waktu antrian sistem menggunakan RFID dan perangkat lunak. 


\section{ILKOM Jurnal IImiah Volume 10 Nomor 1 April 2018}

Tabel 2. Tabel Analisis Data Dari Kiri ke kanan untuk Studi Kasus pertama, kedua dan ketiga

\begin{tabular}{|c|c|c|c|c|c|}
\hline Pasien & \multirow{2}{*}{ Data } & $\begin{array}{l}\text { Waktu Antrian } \\
\text { (Rumah Sakit) }\end{array}$ & $\begin{array}{l}\text { Waktu Antrian } \\
\text { (Sistem) }\end{array}$ & Selisih & \\
\hline $\mathrm{n}$ & & $Y_{1}$ & $Y_{2}$ & D & $D^{2}$ \\
\hline 1 & 1 & 14 & 4 & 10 & 100 \\
\hline 2 & 50 & 12 & 5 & 7 & 49 \\
\hline 3 & 18 & 15 & 1 & 14 & 196 \\
\hline 4 & 46 & 15 & 1 & 14 & 196 \\
\hline 5 & 47 & 10 & 5 & 5 & 25 \\
\hline 6 & 39 & 11 & 4 & 7 & 49 \\
\hline 7 & 19 & 12 & 1 & 11 & 121 \\
\hline 8 & 8 & 15 & 3 & 12 & 144 \\
\hline 9 & 1 & 14 & 4 & 10 & 100 \\
\hline 10 & 17 & 13 & 3 & 10 & 100 \\
\hline 11 & 36 & 10 & 3 & 7 & 49 \\
\hline 12 & 44 & 13 & 3 & 10 & 100 \\
\hline 13 & 50 & 12 & 5 & 7 & 49 \\
\hline 14 & 37 & 13 & 5 & 8 & 64 \\
\hline 15 & 41 & 13 & 2 & 11 & 121 \\
\hline 16 & 17 & 13 & 3 & 10 & 100 \\
\hline 17 & 45 & 14 & 5 & 9 & 81 \\
\hline 18 & 5 & 10 & 1 & 9 & 81 \\
\hline 19 & 22 & 15 & 5 & 10 & 100 \\
\hline 20 & 18 & 15 & 1 & 14 & 196 \\
\hline 21 & 7 & 14 & 3 & 11 & 121 \\
\hline 22 & 23 & 15 & 5 & 10 & 100 \\
\hline 23 & 37 & 13 & 5 & 8 & 64 \\
\hline 24 & 15 & 10 & 3 & 7 & 49 \\
\hline 25 & 15 & 10 & 3 & 7 & 49 \\
\hline Jum & & 321 & 83 & 238 & 2404 \\
\hline $\mathrm{Mes}$ & & 12.84 & 3.32 & & \\
\hline Selif & & 9 & & & \\
\hline
\end{tabular}

\begin{tabular}{|c|c|c|c|c|c|}
\hline Pasien & \multirow{2}{*}{ Data } & $\begin{array}{l}\text { Waktu Antrian } \\
\text { (Rumah Sakii) }\end{array}$ & $\begin{array}{l}\text { Waktu Antrian } \\
\text { (Sistem) }\end{array}$ & Selisish & \\
\hline$n$ & & $Y_{1}$ & $Y_{2}$ & $\bar{D}$ & $\mathrm{D}^{2}$ \\
\hline 1 & 49 & 12 & 4 & 8 & 64 \\
\hline 2 & 16 & 12 & 2 & 10 & 100 \\
\hline 3 & 8 & 15 & 3 & 12 & 144 \\
\hline 4 & 40 & 10 & 5 & 5 & 25 \\
\hline 5 & 20 & 14 & 4 & 10 & 100 \\
\hline 6 & 45 & 15 & 1 & 14 & 196 \\
\hline 7 & 27 & 11 & 2 & 9 & 81 \\
\hline 8 & 1 & 14 & 4 & 10 & 100 \\
\hline 9 & 49 & 12 & 4 & 8 & 64 \\
\hline 10 & 14 & 13 & 1 & 12 & 144 \\
\hline 11 & 5 & 10 & 1 & 9 & 81 \\
\hline 12 & 16 & 12 & 2 & 10 & 100 \\
\hline 13 & 10 & 14 & 3 & 11 & 121 \\
\hline 14 & 30 & 11 & 5 & 6 & 36 \\
\hline 15 & 24 & 12 & 2 & 10 & 100 \\
\hline 16 & 10 & 14 & 3 & 11 & 121 \\
\hline 17 & 18 & 15 & 1 & 14 & 196 \\
\hline 18 & 26 & 14 & 1 & 13 & 169 \\
\hline 19 & 36 & 10 & 3 & 7 & 49 \\
\hline 20 & 44 & 13 & 3 & 10 & 100 \\
\hline 21 & 30 & 11 & 5 & 6 & 36 \\
\hline 22 & 48 & 11 & 1 & 10 & 100 \\
\hline 23 & 16 & 12 & 2 & 10 & 100 \\
\hline 24 & 18 & 15 & 1 & 14 & 196 \\
\hline 25 & 2 & 10 & 5 & 5 & 25 \\
\hline 26 & 36 & 10 & 10 & 0 & 0 \\
\hline 27 & 25 & 10 & 3 & 7 & 49 \\
\hline 28 & 3 & 14 & 1 & 13 & 169 \\
\hline 29 & 15 & 10 & 3 & 7 & 49 \\
\hline 30 & 23 & 15 & 5 & 10 & 100 \\
\hline Jum & & 371 & 90 & 281 & 2915 \\
\hline Me & & 12.4 & 3 & & \\
\hline Sel & & & & & \\
\hline
\end{tabular}

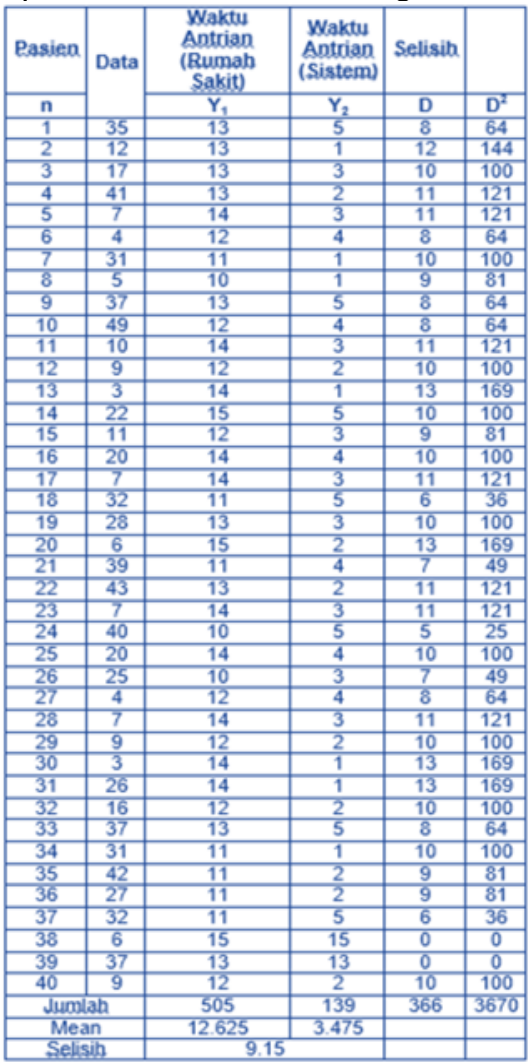

Dari hasil perhitungan dengan rumus pada persamaan (3) untuk data pada pekan 1 diperoleh $t$ hitung $=19.04$ yang lebih besar dari nilai $t$ table $=2.064$. Untuk analisis untuk pekan kedua nilai thitung $=$ 16.5 lebih besar dari nilai table $=2.045$ dan analisis pekan ketiga nilai thitung $=20.3$ lebih besar dari nilai $t_{\text {table }}=2.023$. Karena semua maka kita tolak $\mathrm{H}_{\circ}$ dan kita terima $\mathrm{H}_{\mathrm{A}}$. Dengan demikian, $\bar{Y}_{1} \neq \bar{Y}_{2}$, yaitu waktu antri Sistem Konvensional dan Sistem RFID tidak sama. Dapat disimpulkan bahwa rata-rata waktu antri Sistem RFID lebih singkat daripada waktu antri Sistem Konvensional sehingga sistem RFID mampu mempersingkat waktu antri pasien untuk proses rekam medis.

Implementasi sistem untuk perangkat lunak dilakukan dengan menguji setiap form dalam sistem yang dibuat. Berikut beberapa tampilan untuk form login yang error dan berhasil masuk sistem.

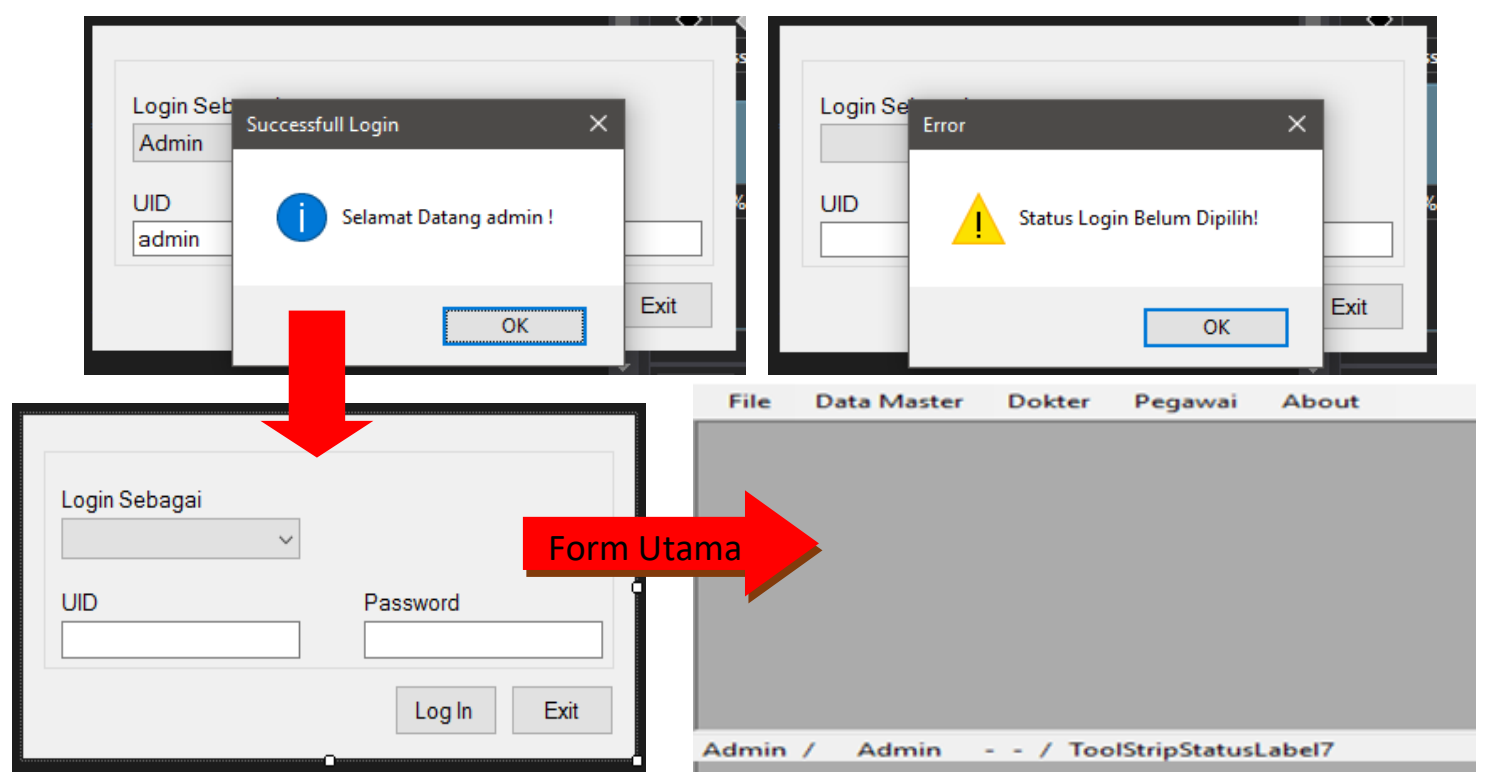

Gambar 5. Uji form Login dan Menu Utama 


\section{ILKOM Jurnal Ilmiah Volume 10 Nomor 1 April 2018}

Form menu utama pada gambar 5 merupakan form yang akan muncul ketika pengguna telah berhasil melakukan login. Jika pengguna memilih status login sebagai admin, makan form utama yang akan muncul adalah form utama dengan menu Data Master (Data Pasien, Data Dokter, Data Pegawai, Data Polis dan Data User), Transaksi (Pendaftaran Rawat Jalan, Pembayaran Rawat Jalan), Log Out dan Exit. Terdapat beberapa form input data master user, pasien, dokter, dan pegawai yang bertujuan untuk menambah data user, pasien, dokter dan pegawai ke dalam sistem dimana hak akses sesuai dengan user. Admin memiliki hak akses untuk semua pengguna.

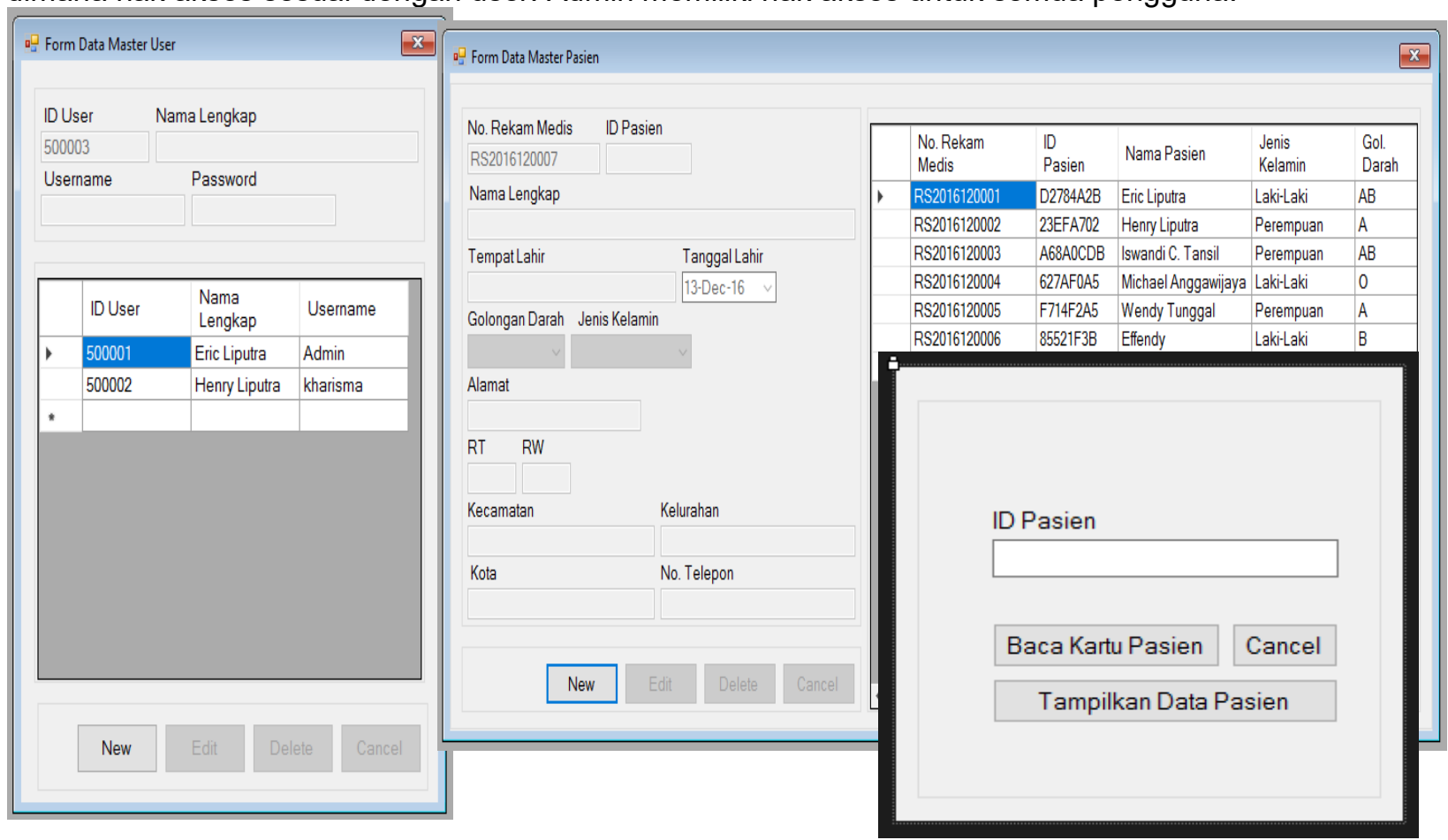

Gambar 6. Tampilan Form Data Master User, Data Master Pasien dan Form Baca Kartu Pasien

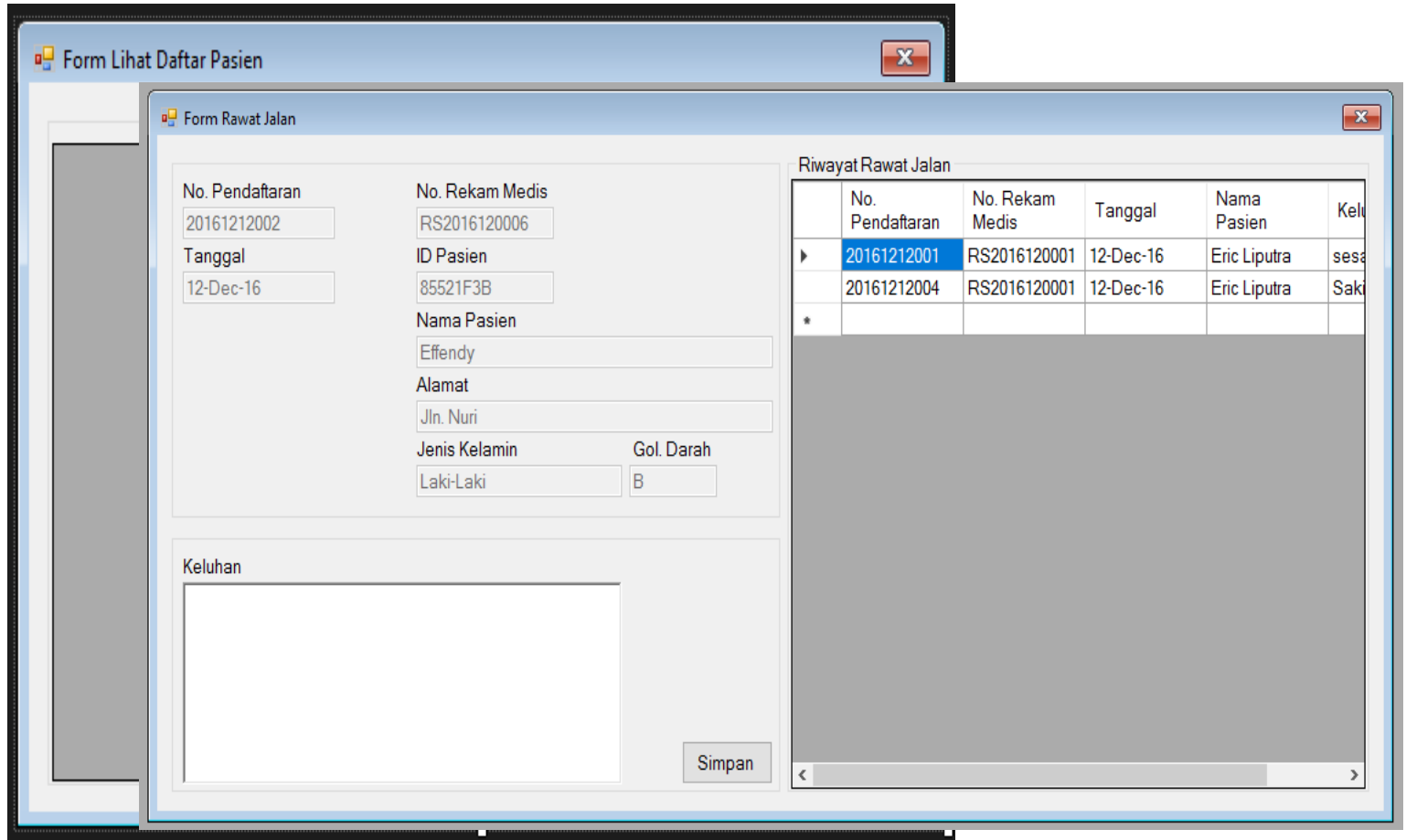

Gambar 7. Form Lihat Daftar Pasien dan Form Rawat Jalan

Form pada gambar 6 bertujuan untuk menambah, mengubah, dan menghapus data. Form input data master pasien dan user ini bertujuan untuk menambah data pasien dan user. 


\section{ILKOM Jurnal Ilmiah Volume 10 Nomor 1 April 2018}

Form paling kanan adalah form untuk membaca kartu pasien yang ingin melakukan rawat inap degan dokter tertentu. Form Lihat Daftar Antrian Rawat Jalan hanya dapat diakses oleh dokter yang berhasil melakukan login. Form pada gambar 7 hanya akan menampilkan daftar pasien yang memilih dokter tertentu untuk melakukan rawat jalan.

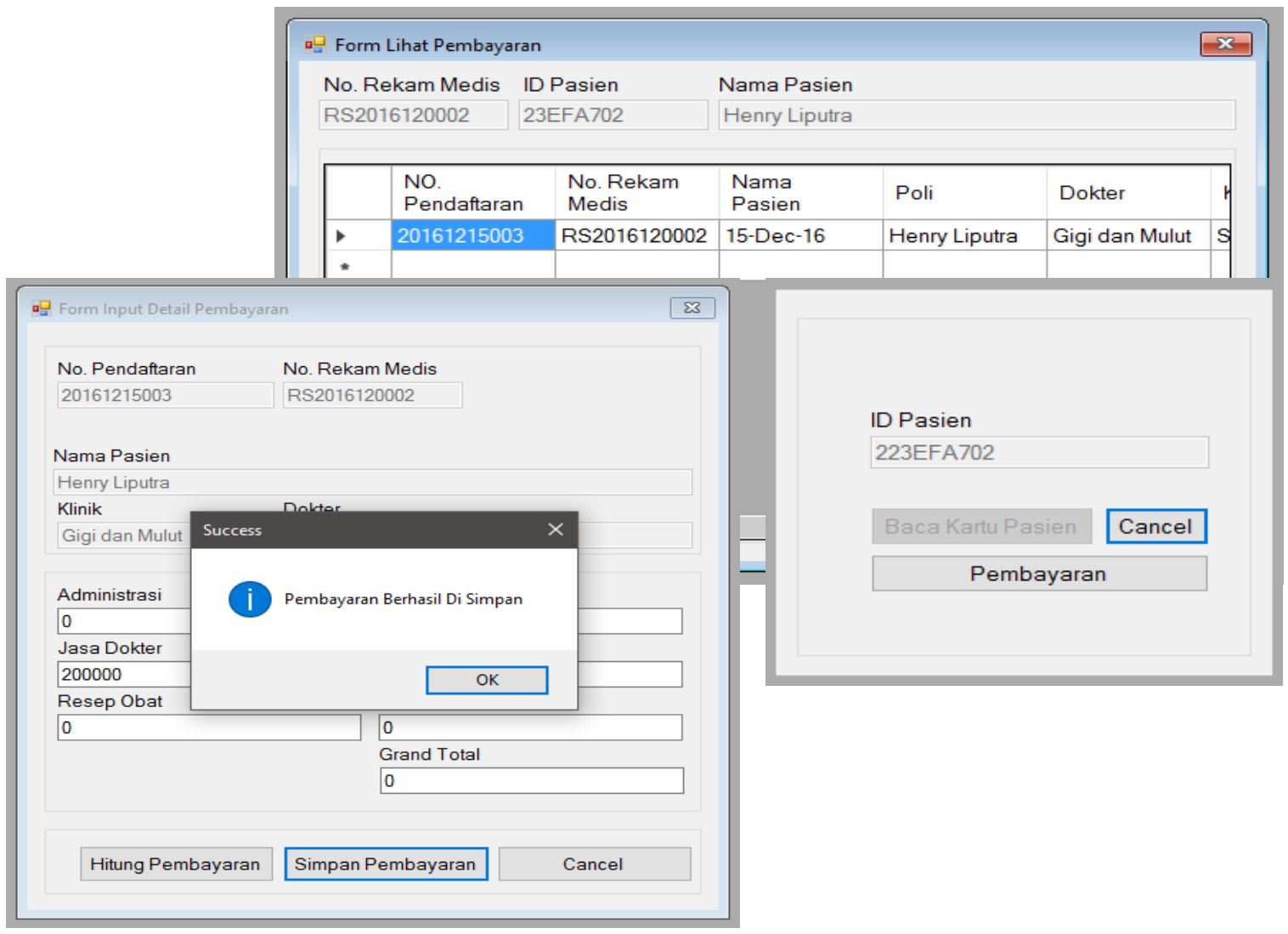

Gambar 8. Form Lihat Pembayaran, Form Input Detail Pembayaran dan Form Baca Kartu Pasien.

Pada gambar 8 terlihat form untuk melakukan pembayaran pasien. Jika pasien ingin melakukan pembayaran maka hal pertama yang harus dilakukan adalah membaca kartu pasien. Kemudian jika terbaca maka akan tampil form lihat pembayaran seperti gambar 8. Jika pengguna menekan ID dari pasien maka akan muncul form input detail pembayaran. Seperti terlihat pada gambar 8, pembayaran berhasil disimpan. Tombol hitung pembayaran adalah tombol yang digunakan untuk transaksi pembayaran pada kasir. Seluruh form yang tampil pada gambar 5, 6, 7 dan 8 telah diuji dengan pengujian black box. Semua fungsi dari setiap form dalam sistem bekerja dengan baik.

\section{Kesimpulan dan saran}

Dari penelitian yang telah dilakukan, dapat disimpulkan bahwa:

1. Sistem yang dirancang berjalan sesuai dengan kebutuhan penelitian setelah dilakukannya pengujian black box testing terhadap sistem yang dirancang.

2. Sistem mampu mempercepat proses antrian rekam medis pasien pada rumah sakit dengan memiliki waktu rata - rata sebesar 3.6 menit dengan selisih waktu 9.4 menit dari waktu rata rata antri sistem konvensional sebesar 12.6 menit.

Aplikasi ini belum mencakup analisis sistem pembayaran yang terintegrasi. Hal tersebut menjadi satu pengembangan yang dianggap perlu dalam penelitian selanjutnya. Pengembangan lanjutan yang dapat dilakukan, yaitu:

1. Aplikasi dapat menghitung pembayaran secara otomatis sejalan dengan proses pemeriksaan yang dilakukan pasien rawat jalan mulai dari laboratorium, radiologi, resep obat dan pemeriksaan lainnya.

2. Pemanfaatan QR Code sebagai pengganti RFID pada kartu pasien yang dapat dibuatkan aplikasi berbasis web untuk memudahkan pasien mendaftarkan diri via online dimana saja ataupun ketika sedang dalam perjalanan ke rumah sakit melalui smartphone mereka. 


\section{Daftar Pustaka}

[1] Arikunto, S. 2010. Prosedur Penelitian: Suatu Pendekatan Praktik. Edisi Revisi 2010. Jakarta: Rineka Cipta

[2] Brady, M. dan Loonam, J. 2010. Exploring the Use of Entity-Relationship Diagramming as a Technique to Support Grounded Theory Inquiry. Bradford: Emerald Group Publishing.

[3] Fitrah, R. 2012. Analisis Dan Perancangan Perpustakaan Digital Dan Sistem Otomasi Perpustakaan Sma Negeri 3 Palembang. Palembang: Universitas Bina Darma.

[4] Gustiana, A.R. 2009. Sistem Informasi Persediaan Barang studi kasus pada PT. Insopanel Dunia. Bandung: Universitas Komputer Indonesia.

[5] Hamid, 2010, "Pengembangan Sistem Parkir Terkomputerisasi Dengan Otomatisasi Pembiayaan Dan Penggunaan RFID Sebagai Pengenal Untuk Pengguna", SNAT, I 2010, pp. 2.

[6] Landt, J, 2005. "The History of RFID", IEEE Potensials, vol. 24, no. 4, pp. 8-11.

[7] Lestari, E. 2011. Sistem Informasi Rekam Medik Pada Rumah Sakit Bersalin Graha Rap Tanjung Balai Karimun. Palembang: Universitas Sriwijaya.

[8] M, Syafii, Membangun aplikasi berbasis PHP dan MySQL. Yogyakarta: Andi, 2004.

[9] Magdalena, 2011. Simulasi Antrian Dengan Menggunakan Metode Monte Carlo. Medan: Universitas Sumatera Utara.

[10] Maryono, 2005. "Dasar-dasar Radio Frequency Identification (RFID) Yang Berpengaruh Di Perpustakaan". Media Informasi Vol. XIV No. 20 Th. 2005.

[11] Rosmaini, E. 2010. Perancangan E-Commerce Studio Photo. Medan: Universitas Sumatera Utara.

[12] Susanti, Roza dan Budi Bakhtiar, "Pengaturan Portal Pada Pengurutan Parkir Mobil dengan Menggunakan RFID dan PC". Padang: Elektron Vol. 1 No. 2, 2009.

[13] Want, Roy, 2004, "Enabling Ubiquitous Sensing With RFID, Computer", Vol. 37, No. 4, 2004, pp. 84-86. 